удк 796.032.2.063.4+159.9+331.015

Володимир Приходько

Придніпровська державна академія фізичної культури і спорту

ORCID ID 0000-0001-6980-1402

Олександр Томенко

Сумський державний педагогічний

університет імені A. C. Макаренка

ORCID ID 0000-0002-1097-965X

Василь Босько

Сумський державний університет

ORCID ID 0000-0002-8796-2362

Діана Бермудес

Сумський державний педагогічний

університет імені А. С. Макаренка

ORCID ID 0000-0001-7573-6598

Дмитро Балашов

Сумський державний педагогічний

університет імені A. C. Макаренка

ORCID ID 0000-0001-8020-4721

DOI 10.24139/2312-5993/2019.07/100-116

\title{
ПРОБЛЕМА ТЕХНОЛОГІЇ В РЕФОРМІ СФЕРИ СПОРТУ В УКРАЇНІ
}

Мета дослідження полягає в обгрунтуванні проблеми використання соціальних технологій у ході підготовки та проведення реформи сфери спорту. Методи дослідження: аналіз та узагальнення літературних джерел і матеріалів мережі Internet, синтез, абстрагування, індукція й дедукція. У статmі подані результати аналізу пропозицій науковців щодо реформування сфери спорту, які можуть навіть бути обрані в якості стратегії потрібних змін. Сенс їхньої критики полягає в демонстрації недостатності самої лище, навіть якісно розробленої стратегії для початку потрібних перетворень. Засобом есрективного впливу на процес змін є спеціально створена технологія реформування сфери спорту, загальні вимоги до подібних технологій визначені й описані.

Ключові слова: рефрорма сфрери спорту, стратегія реформи, реформатор, позитивна, негативна й ситуативна частини змін у ході реформи, сочіальна технологія.

Постановка проблеми. Тема реформи сфери спору в Україні особливо активно почала обговорюватися в нашому суспільстві після революції гідності, коли до порядку денного було поставлено питання глибинних змін у різних сферах державного управління. Саме в цей час почали гучно лунати заклики до відмови від подальшої експлуатації залишків радянської системи спортивної підготовки, яка вже себе віджила. 
Адже стало очевидно, що перехід від адміністративно-командної до ринкової економіки кличе за собою зміни також в інших сферах.

Передусім звернемо увагу на пропозиції практиків спорту, які з'явилися в цей час: В. Бульби (Советник министра молодежи и спорта: спонсирование спорта выведет деньги бизнеса из тени), А.Ігнатенка (Игнатенко), Д. Качуровського (Качуровский) і О. Ларіна (Ларин), які виклали свої думки щодо спрямованості і змісту реформи. Привернули свою увагу до цієї актуальної теми також науковці О.Гацуля (Гацуля, 2015), О.Гонтарук (Гонтарук, 2017), В. Приходько (Приходько, 2018а; 20186; 2014), І. Шевчук (Шевчук, 2014) та інші.

Аналіз актуальних досліджень. В останні роки все більше уваги стало приділятися зарубіжному досвіду в управлінні сферою спорту: В. Бескровна (Бескровная, 2008), М. Журба (Журба, 2017), Р. Куртинайтіс (Куртинайтис), Ю. Павленко (Павленко, 2012) і О. Шинкарук (Шинкарук, 2012). Нарешті почало обговорюватися важливе місце науки і науковців в забезпеченні реформи сфери спорту (Приходько та ін., 2016).

Все вказане прикувало увагу до теми технології проведення реформи як такої (Технология проведения реформ для страны с переходной экономикой и молодой демократией; Шишигина та ін., 2012), між тим вона до останнього часу не була наближена до сфери спорту. Тож не була показана роль технології і в реформі спорту.

Гіпотеза дослідження полягає в науковому передбаченні можливості використання в проведенні реформи сфери спорту так званої соціальної технології, яка сприятиме впровадженню обраної стратегії змін.

Мета дослідження: обґрунтувати проблему використання соціальних технологій у ході підготовки та проведення реформи сфери спорту.

Методи дослідження: узагальнення літератури і матеріалів 3 Інтернету, абстрагування, аналіз і синтез, індукція та дедукція.

Виклад основного матеріалу. 3 поміж інших помітних праць звернемо увагу, насамперед, на ґрунтовний матеріал О. Шинкарук, М. Дутчака та Ю. Павленка (Шинкарук та ін., 2013), які поставили за мету здійснити комплексний аналіз виступу спортсменів України на Іграх XXX Олімпіади, окреслити основні проблеми олімпійської підготовки в Україні та визначити перспективи ії вдосконалення. Автори починають обговорення теми з ревізії виявлених ними проблем, кожну з яких потім детально розкривають. Наразі авторами названі такі проблеми:

1. Малоефективна система управління олімпійською підготовкою, залучення до її організації значної кількості суб'єктів спортивного руху.

2. Нераціональне використання наявних ресурсів для олімпійської підготовки.

3. Низька ефективність заключного етапу підготовки до Ігор Олімпіади. 
4. Незадовільне матеріально-технічне забезпечення олімпійської підготовки.

5. Недостатній рівень конкуренції при формуванні збірних команд України.

6. Низьке наукове та медичне забезпечення олімпійської підготовки.

Указавши кожну з наявних проблем, науковці далі визначають перспективи їх удосконалення, які можна вважати баченням авторами суттєвих і позитивних змін у спорті, які ми далі подаємо без купюр, але з нашими критичними запитаннями до кожної з пропозицій.

1. Реформування системи управління розвитком спорту та олімпійської підготовки.

Необхідно чітко розмежувати повноваження суб'єктів сфери фізичної культури і спорту для уникнення дублювання функцій щодо розвитку спорту та олімпійської підготовки. Зокрема, доцільно відповідальність за проведення олімпійської підготовки покласти на Національний олімпійський комітет України (далі - НОК) з виділенням для цього відповідних асигнувань 3 державного бюджету. НОК укладає угоди з кожним спортсменом та його особистим тренером, які залучені до олімпійської підготовки, де закріплюються конкретні зобов'язання сторін щодо підготовки до Ігор чергової Олімпіади, у т. ч. участь у міжнародних змаганнях протягом 4річного циклу підготовки.

Відповідальність за розвиток дитячого, дитячо-юнацького, резервного спорту всередині країни має бути покладена на центральний орган виконавчої влади у сфері фізичної культури і спорту, добровільні спортивні товариства, спортивні федерації, регіональні та місцеві органи управління. При цьому необхідно розставити пріоритети, заохочуючи розвиток тих чи інших видів спорту в конкретних територіях чи організаціях, де $є$ або може бути розвинена відповідна матеріальна база та кадровий потенціал тощо.

Питання до пропозиції 1, адже Amicus Plato, sed magis arnica Veritas.

Дійсно, потрібно забезпечити «чітке розмежування повноважень суб'єктів сфери фізичної культури і спорту для уникнення дублювання функцій щодо розвитку спорту та олімпійської підготовки». Але автори не вказують, кого саме вони мають на увазі під поняттям «суб'єкт» в олімпійській підготовці. Чи відносять вони до них також інші органи державного управління, або органи державної влади на місцях, національні (всеукраїнські) федерації з видів спорту тощо? Отже, виглядає так, що всі вони не вважаються суб'єктами реформи управління розвитком спорту та формування сучасної системи олімпійської підготовки. Звідки ж тоді з'являться нові підготовлені спортсмени, з якими «НОК укладе угоди щодо підготовки до Ігор чергової Олімпіади»? 
А як розуміти, порівнюючи першу, а також наступну тезу про відповідальність «за розвиток дитячого, дитячо-юнацького, резервного спорту», коли називаються «добровільні спортивні товариства, спортивні федерації, регіональні та місцеві органи управління»? I в чому сутність новації покласти відповідальність за «матеріальну базу, кадрове забезпечення, організацію тренувальної та змагальної діяльності на центральний орган виконавчої влади у сфері фізичної культури і спорту, хто саме і де це має забезпечити?

А як бути з пропозицією «налагодити ефективний державний та громадський контроль за виконанням раніше прийнятих рішень щодо розвитку спорту та олімпійської підготовки»? Які тут механізми забезпечення такого дієвого контролю?

2. Здійснення олімпійської підготовки з видів спорту, у яких Україна здатна мати олімпійські медалі в найближчі 8 років. Необхідно орієнтуватися на розвиток пріоритетних видів спорту і дисциплін, що мають з одного боку багаті традиції підготовки, відповідний потенціал спортсменів, які мають високу ймовірність отримання олімпійської нагороди, тренерські кадри, а з іншого - недостатню конкуренцію на міжнародній арені та високу «медалеємність». На сучасному етапі для України це, на думку авторів, такі види спорту: легка атлетика, спортивна гімнастика, важка атлетика, бокс, фехтування, стрільба кульова, боротьба вільна, дзюдо, веслування, плавання.

\section{Питання до пропозиції 2.}

Хто саме має визначати «пріоритетні види спорту і дисципліни», приміром, для Тернопільської і Чернігівської областей? Це мають бути «легка атлетика, спортивна гімнастика, важка атлетика, бокс, фехтування, стрільба кульова, боротьба вільна, дзюдо, веслування на байдарках і каное, веслування академічне, плавання»? Чи може з урахуванням «традицій підготовки, відповідного потенціалу спортсменів, які мають високу ймовірність отримання нагороди і кваліфікованих тренерських кадрів» за рішенням області це буде, біатлон?

3. Залучення до олімпійської підготовки у пріоритетних видах спорту спортсменів світового рівня.

НОК України має укладати угоди про олімпійську підготовку лише зі спортсменами, які за результатами участі в офіційних міжнародних змаганнях, рейтингом міжнародних спортивних федерацій, висновків експертів входять до найсильніших атлетів у своєму виді спорту, дисципліні, ваговій категорії тощо, які разом із тренером несуть персональну відповідальність за виконання взятих на себе зобов'язань щодо результатів участі в Іграх наступної Олімпіади. Загальна кількість таких спортсменів не повинна перевищувати 100 осіб. Необхідно здійснювати щорічне оновлення цього контингенту (в межах 10-15\%) за рахунок вилучення осіб, які 
погіршили спортивні результати, та включення додатково нових перспективних спортсменів.

\section{Питання до пропозиції 3.}

Неможливо заперечувати тезу про «залучення до олімпійської підготовки у пріоритетних видах спорту спортсменів світового рівня»? Але ця тема $\epsilon$ похідною від формування сучасної системи підготовки спортсменів і виховання спортивного резерву, про які взагалі не йдеться?

4. Забезпечення виходу на пік готовності в 4-річному циклі на Іграх чергової Олімпіади 50-70 \% спортсменів, які були залучені до олімпійської підготовки.

Основним елементом підвищення кваліфікації тренерів має стати обов'язкове щорічне підвищення кваліфікації шляхом участі на відповідних курсах, стажування в зарубіжних центрах та складання спеціального екзамену.

Залучення до здійснення олімпійської підготовки окремих вітчизняних спортсменів провідних зарубіжних фахівців за напрямами їх підготовки.

НОК налагодити дієвий механізм моніторингу за складанням та реалізацією індивідуальних цільових програм олімпійської підготовки спортсменів.

\section{Питання до пропозиції 4.}

Дуже важливо «забезпечити вихід на пік готовності в 4-річному циклі на Іграх чергової Олімпіади 50-70 \% спортсменів, які були залучені до олімпійської підготовки». А як саме пропонується це забезпечити?

Відомо, що тренери мають проходити і проходять підвищення кваліфікації на «відповідних курсах», а дехто навіть через «стажування у зарубіжних центрах». Тож, як саме пропонується покращити якість підвищення кваліфікації тренерів?

У який спосіб НОК може «налагодити дієвий механізм моніторингу за складанням та реалізацією індивідуальних цільових програм олімпійської підготовки спортсменів»?

Як саме передбачається «здійснювати комплексне та системне вирішення різноманітних питань щодо створення належного фінансового та матеріально-технічного забезпечення, медичного й наукового супроводу олімпійської підготовки»?

5. Створення сучасних центрів олімпійської підготовки.

Формування 5-7 національних центрів олімпійської підготовки 3 об'єднанням відповідних установ, організацій, підприємств, здатних забезпечити повний спектр якісних послуг національним командам: тренувальні, навчальні, наукові, медичні, інформаційні, матеріальнотехнічні, сервісні та адміністративні. 
Доцільним видається в межах реалізації ініціативи керівництва держави про зміцнення матеріально-технічної бази фізичної культури і спорту (програма «3х27») у регіонах держави в першу чергу спрямувати відповідне фінансування та зусилля на будівництво сучасних баз олімпійської підготовки на місцях з урахуванням пріоритетності видів спорту, наявних спортивних традицій та кваліфікованих тренерських кадрів.

Забезпечення кожної національної федерації 1-3 сучасними тренувальними спортивними базами, які відповідають вимогам міжнародних федерацій для проведення змагань високого рівня. Будівництво спортивних споруд і баз олімпійської підготовки повинне враховувати особливості регіону: наявні кліматичні умови, кадровий потенціал, контингент спортсменів тощо.

\section{Питання до пропозиції 5.}

Який саме шлях пропонується, щоб «створити 5-7 сучасних центрів олімпійської підготовки»?

Хто і як саме має забезпечити «будівництво сучасних баз олімпійської підготовки на місцях з урахуванням пріоритетності видів спорту»?

У який спосіб пропонується «забезпечення кожної національної федерації 1-3 сучасними тренувальними спортивними базами»?

6. Удосконалення медичного та фармакологічного забезпечення олімпійської підготовки.

Необхідно здійснювати щорічне підвищення кваліфікації лікарів, які задіяні до медичного обслуговування спортсменів, що здійснюють олімпійську підготовку.

Національному антидопінговому центру забезпечити розробку та реалізацію програми з профілактики використання спортсменами заборонених засобів та методів.

\section{Питання до пропозиції 6.}

Як саме передбачається забезпечити «удосконалення медичного та фармакологічного забезпечення олімпійської підготовки»? і далі, як саме потрібно якісно «...здійснювати щорічне підвищення кваліфікації лікарів, які задіяні до медичного обслуговування спортсменів, що здійснюють олімпійську підготовку»?

у який спосіб i за рахунок яких ресурсів «національному антидопінговому центру забезпечити розробку та реалізацію програми 3 профілактики використання спортсменами заборонених засобів та методів»?

7. Упровадження в олімпійську підготовку сучасних наукових технологій: 
- створення у структурі центрів олімпійської підготовки комплексів із науково-методичного забезпечення національних команд за принципом упроваджувальних дослідних центрів;

- налагодження роботи стаціонарних та мобільних наукових лабораторій на основних базах олімпійської підготовки;

- реалізація державної програми з упровадження інноваційних технологій (інформаційних, генних, нанотехнологій тощо) у спорт найвищих досягнень із залученням провідних навчальних, наукових закладів, організацій та підприємств країни;

- створення національної інформаційно-комп'ютерної мережі 3 наданням довідково-консультативних, науково-технічних, контрольноуправлінських послуг фахівцям, які задіяні в олімпійській підготовці;

- налагодження системного покращення інструментального оснащення наукової діяльності зі створенням стаціонарних науково-діагностичних стендів для споріднених видів спорту, мобільних діагностичних лабораторій комплексної та вибіркової спрямованості для проведення обстежень спортсменів у природних умовах тренувальної та змагальної діяльності;

- виділення на потреби спортивної науки не менше 2 \% загального фінансування підготовки національних команд.

\section{Питання до пропозиції 7.}

«Створення у структурі центрів олімпійської підготовки комплексів із науково-методичного забезпечення національних команд за принципом упроваджувальних дослідних центрів» та «налагодження роботи стаціонарних та мобільних наукових лабораторій на основних базах олімпійської підготовки» - це мова про ті центри, які ще не створені? Тож хто саме і за рахунок яких ресурсів має їх створити?

А як пропонується забезпечити «реалізацію державної програми 3 упровадження інноваційних технологій у спорт найвищих досягнень із залученням провідних навчальних, наукових закладів, організацій та підприємств країни»?

А як саме «створити національну інформаційно-комп'ютерну мережу з наданням довідково-консультативних, науково-технічних, контрольноуправлінських послуг фахівцям, які задіяні в олімпійській підготовці»?

Як забезпечити «налагодження системного покращення інструментального оснащення наукової діяльності зі створенням стаціонарних науково-діагностичних стендів для споріднених видів спорту, мобільних діагностичних лабораторій комплексної та вибіркової спрямованості для проведення обстежень спортсменів у природних умовах тренувальної та змагальної діяльності»?

Яким способом бачиться вирішення питання «виділення на потреби спортивної науки не менше 2 \% загального фінансування підготовки національних команд»? 
Узагальнюючи, запропоновані перспективи вдосконалення основних проблем олімпійської підготовки в Україні, зазначимо таке. По-перше, запропонований підхід, у випадку його схвалення центральним органом державного управління сферою спорту, може отримати статус стратегії, але яка сама по собі не здатна забезпечити формування сучасної системи підготовки спортсменів. Стратегія за своєю сутністю має давати визначення основних напрямів і шляхів досягнення цілей зміцнення, зростання й забезпечення виживання організації (долі реформи - авт.) у довгостроковій перспективі на основі концентрації зусиль на певних пріоритетах (Сутність стратегії). Натомість тактика, що має сприяти ії виконанню - це концептуальна дія, яка здійснюється у вигляді одного або більшої кількості конкретних завдань (Тактика).

По-друге, ці визначені О. Шинкарук, М. Дутчаком та Ю. Павленком «перспективи вирішення основних проблем» потрібно розцінювати як позитивні кроки, які мають бути підкріплені засобами їх реалізації.

По-третє, указані авторами ходи актуалізують потребу в розробці та використанні особами відповідальними за проведення реформи у сфері спорту відповідної соціальної технології формування сучасної системи підготовки спортсменів в Україні.

Мета будь-якої реформи спрямована на досягнення конкурентоспроможності держави в певному сегменті. Реформа містить три компоненти: позитивну частину, негативну частину і ситуативну частину.

Позитивна частина реформи. Вона містить орієнтири про те, яка зміна має відбутися, щоб держава отримала прорив і стала більш конкурентоспроможною. Щодо сфери спорту, то тут результатом реформи виступає формування сучасної системи підготовки спортсменів, яка враховує позитивні приклади та існуючі світові тенденції в цій царині, визначені пріоритети внутрішньої політики щодо максимально можливої децентралізації влади й заохочення територій до розв'язання нагальних суспільних проблем.

Негативна частина реформи. Під час реформування сфери спорту очікуваний супротив тих, хто звикли жити по-старому, адже реформа призводить до змін у становищі людей. Для деяких вона відкриває нові перспективи, натомість інтереси інших від неї страждають. Після того, як проект реформи оголошено, чи не кожна реформа отримує прихильників і противників, між ними зазвичай починається конфлікт. Його інтенсивність залежить від змісту реформи. Такий конфлікт може привести до того, що реформа виявиться під загрозою скасування, як це було в 1970-ті роки в ході дуже продуктивної з точки зору підготовки олімпійців спроби в Одеській області щодо створення так званих «одновідомчих центрів» із розвитку олімпійських видів спорту (Попов, 2001; Приходько, 2018а). 
Ситуативна частина реформи. Ситуативна частина, на відміну від перших двох, що вказують на те, який саме результат повинен бути досягнутий, належить вже безпосередньо до актуальної ситуації процесу реформування: саме в ній з'являються кількісні показники і конкретні механізми, які мають привести до реалізації задуманого. При розробці цієї складової, яка і $є$ предметом соціальної технології, що має бути створена, у підготовленому офіційному Календарному плані реформи зазначається: які процедури, ким, як саме і в які строки повинні змінитися, які нормативні акти треба скасувати, а які нові прийняти, як і коли повинні з'явиться ті або інші нові об'єкти і суб'єкти права.

Загальна ж логіка дій реформатора для забезпечення реалізації змін, за С. В.Поповим (Попов) передбачає дотримання таких вимог: 1. У ініціатора реформи має бути уявлення про бажане майбутнє об'єкту перетворень. Але цього недостатньо, адже вироблена ним модель може бути і безвідповідальним прожектом, і революційною дією, а негарно підготовленою реформістською логікою. 2. Таким чином, у нього повинне бути реалістичне, максимально повне уявлення про те, що в дійсності являє собою об'єкт перетворень до початку змін. 3. У нього має існувати установка на «ненасильство» по відношенню до наявної ситуації. Замість того, щоб силоміць переробляти існуючу дійсність, підминати об'єкт під образ майбутнього, справжній реформатор намагається бути не гончарем, який формує глину під задумані ідеальні моделі, але сіячем, який засіває ґрунт справжнім насінням майбутнього, або садівником, що прививає до підщепи справжню щепу майбутнього. 4. Для цього йому потрібно вміти «згортати» свої уявлення про бажане майбутнє в деякі мінімальні елементи, у деякі «клітинки» майбутнього, які вже сьогодні можна впроваджувати при мінімальному «опорі матеріалу» дійсності.

Яку ж стратегію можуть обрати ті політичні сили, які намагаються працювати з широкими верствами населення, насправді дієво, не на рівні самої тільки пропаганди, а дійсно орієнтуючись на глибокі зміни?

По-перше, необхідно, щоб управлінський шар зайнявся реформуванням соціально-виробничої системи, переводячи ії у сфері спорті з «ручного режиму» керівництва на суто економічні відносини.

По-друге, необхідним $є$ дійсне, глибоке реформування системи державного управління сфери спорту, а не відволікання на ті, що не мають ніякого відношення до реальної реформи необов'язкові теми. Об'єктом політичного управління має стати сам апарат, а метою управління створення таких умов, за яких чиновницька корпорація як «соціальна машина» буде змушена і зможе провести реформи в спорті. Це і $\epsilon$ контроль громадськості за системою державного управління.

По-третє, в областях, там, де живуть професіонали, треба створювати нові структури «існування спорту», побудовані на принципах, що 
випливають із існуючої традиції розвитку спорту, але з сучасними технологіями управління. Ці структури зможуть скласти конкуренцію директивній системі управління, як це і буває в країнах, більш «просунутих» у частині розвитку громадянського суспільства - щоб не допустити в принципі повторення в майбутньому ситуації, коли апарат буде єдиним хоч якось структурованим суб'єктом реформ, як це відбувається сьогодні.

Соціальна технологія, яка потрібна для здійснення реформи, - це визначений спосіб здійснення діяльності з досягнення суспільно-значущих цілей. Сутність цього способу полягає в раціональному розділенні діяльності на процедури і операції з їхньою наступною координацією і синхронізацією. Це розділення виконується завчасно, свідомо і планомірно на основі та з використанням наукових знань, передового досвіду, а також із урахуванням тієї області, а саме сфери спорту, у якій здійснюється діяльність людини (Сурмин та Туленков, 2004, с. 13).

Технологізація будь якого процесу можлива за умови дотримання низки умов. По-перше, сам процес повинен мати такий ступінь складності, щоб можна було розкласти його на відносно самостійні частини. Відповідно, потреба в технології зумовлюється, передусім, самим об'єктом. По-друге, мають бути засоби, які б дозволили так систематизувати дії суб'єкта змін, аби досягти ефекту, доклавши для цього лише необхідні зусилля (Марков, 1982, с. 160-162).

Зауважимо, що процес проектування соціальної технології реформування існуючої системи підготовки спортсменів потрібно розгортати не від початку до кінця, але від бажаного, уявного кінцевого результату до початку процесу змін. Для цього необхідно чітко уявляти мету й очікуваний результат, знати обсяг потрібних ресурсів і потенціал у виконавців, соціальнотехнологічну сприйнятливість об'єкта технологізації, контекстуальні обмеження й вимоги середовища, у якому відбувається підготовка спортсмена, а також мати достатній набір соціально-технологічних інструментів, які відповідають критеріям оптимальності. Останній крок планується, виходячи з можливих результатів передостаннього, тож на цій основі приймається оптимальне рішення і набір прийнятних для нього засобів. Така процедура повторюється для всіх етапів. При цьому для кожного кроку залишаються визначальними аксіологічні, контекстуальні, ресурсні та інструментальні вимоги (Бурмыкина, 2013, с. 157).

Однак, на цьому проектування соціальної технології не закінчується. В умовах української дійсності, коли ризиків відхилень від наміченого більше, ніж правил, що будуть дотримані для забезпечення успіху, будьяка технологія може бути реалізована лише за допомогою «покрокової» діяльності. Відрефлексований на предмет відповідності меті результат кожного кроку має коригувати наступний і навіть саму технологію. Подібна 
процедура залишає за реформатором свободу вибору, але окреслює «коридор оптимальності», задаючи тим самим межі технологізації. Отже, скоріш за все, можливе одноразове соціально-технологічне рішення складного завдання буде замінене багатократним рішенням низки більш простих задач. Труднощі саме такого підходу проектування соціальних технологій полягають у складнощах вибору параметрів, що характеризують стан системи, і в поділі процесу на етапи (Prykhodko \& Tomenko, 2019). Використання такого методу робить можливим співіснування і взаємне доповнення всередині соціальної технології реформи спорту, що обговорюється, досягнення результатів соціально-перетворювальної діяльності в підвищенні якості процесу підготовки спортсменів.

Нарешті, саме системою цінностей і норм, своєрідністю ментальності як фахівців сфери спорту, так і населення, яке активно цікавиться спортом, його колективного свідомого і несвідомого, характером мікросоціальних практик людей буде обумовлена успішність проведеної технологізації соціального простору спорту вищих досягнень і легітимація їі ідеї громадянами.

Автори вирізняють декілька етапів технологізації процесів у соціальній сфері, які, на нашу думку, варто врахувати й використати в організаціях сфери спорту (Герасимов та Чумак, 2014). Кожен з етапів проявляється в певних умовах.

Зміст першого етапу: відсутність в організації матеріальної зацікавленості в змінах; перевищення резервів соціального потенціалу організації над реальною їх потребою; існуюча відсутність економічної, соціальної, правової відповідальності за ефективне використання трудових ресурсів.

Зміст другого етапу: спеціально підготовлене усвідомлення потреби трудового колективу в забезпеченні більшої ефективності організації.

Сутність третього етапу (безпосереднє здійснення змін): формування стійкої мотивації особистості кожного фахівця до ефективної діяльності організації та усвідомлення необхідності комплексного підходу до використання наявних потенціалів - організаційних, економічних, науковометодичних, соціальних тощо.

Ефективність соціальної технології - це кінцевий результат, що виражається не тільки в економії часу й витрат, але також у забезпеченні стійкості організації в умовах конкуренції в мінливому світі спорту. Отримання стійкості можливе за таких умов: розмежування, поділ і розчленування соціального процесу на пов'язані етапи; координація і поетапність дій; однозначність тлумачення виконуваних операцій i процедур; можливість багаторазового застосування стандартних процедур діяльності для вирішення типових задач. 
Розмежування владних функцій на місцях - перша універсальна технологія. Представницький орган влади виконують функції стратегічного концептуального органу: формують програму розвитку спорту на даній території на перспективу, приміром, визначають олімпійські види спорту для їх пріоритетного розвитку. Тоді як адміністрація відповідного суб'єкта керують сукупністю елементів соціально-економічного і духовно-культурного комплексу території. Однак, на практиці взаємодія представницької і виконавчої гілок влади на місцях часто $€$ неконструктивною, нерідко існує навіть їхнє протистояння, що треба враховувати авторам реформи для сприяння більшому порозумінню між ними.

Друга універсальна технологія - це конструювання раціональної схеми управління розвитком спорту в регіоні. Гострота управлінської ситуації в регіонах ще більш ускладнюється тим, що схеми управління зазвичай конструюються або з нормативних документів, або з минулого досвіду керівників, що заважає рухатись уперед. Через це й не $\epsilon$ використаними потужні різноманітні ресурси регіонів.

Відтак, типова ситуація в регіонах щодо спорту свідчить про низький інформаційно-аналітичний потенціал існуючого регіонального державного управління, інноваційний консерватизм, професійну непідготовленість і нерішучість керівників у вирішенні як стратегічних (для території), так і тактичних питань розвитку спорту. Тому третя універсальна технологія оптимізація інформаційно-аналітичної діяльності в регіоні, яка передбачає підбір, розстановку й підвищення кваліфікації вже працюючих менеджерів спорту. Наступна універсальна технологія покликана реалізувати комплексний системний підхід до аналізу ресурсів, виключення одностороннього підходу, при якому переважно враховуються тільки економічні ресурси.

Одна з найбільш важливих технологій спрямована на формування іміджу регіону як спортивного. Розробка і впровадження технологій, які поширюють позитивні відомості про перші здобуті успіхи в царині спорту, це важлива умова виходу низки регіонів із системної кризи, у якій вони перебувають, перехід до стадії стабілізації та сталого розвитку.

Наостанок зазначимо, що будь-який технологічний проект усього лише творчий ескіз, плановий малюнок (Герасимов та Чумак, 2014). Він не $\epsilon$ догмою, але орієнтиром для людино-творчої діяльності керівників сфери спорту.

Висновки та перспективи подальших наукових розвідок. Наявність пропозицій і побажань щодо того, якою має бути система управління розвитком спорту та практика олімпійської підготовки, які навіть будуть визначені профільним органом державного управління в якості стратегії актуальних перетворень, само по собі не може зрушити тему реформи сфери спорту в Україні. Засобом ефективного впливу на процес змін у сфері 
спорту являється не стільки стратегія, скільки спеціально створена особою, яка самовизначилася в якості реформатора, соціальна технологія, точніше низка технологій, при цьому загальні вимоги до подібних технологій раніше визначені й описані. Відтак, до особи майбутнього реформатора, який взяв на себе відповідальність за здійснення назрілих змін, мають бути пред'явлені відповідні вимоги. Серед іншого важливого він повинен щиро прагнути бажаних змін, володіти не тільки різноманітними знаннями про олімпійський спорт, але й компетентностями, потрібними для розробки й реалізації на практиці відповідних технологій забезпечення змін у сфері спорту.

В умовах української дійсності, саме тому, що ризик відхилень від наміченого плану $€$ суттєвим, будь-яка створена технологія може бути реалізована лише за допомогою «покрокової» діяльності реформатора. Відрефлексований на предмет відповідності кінцевій меті результат кожного кроку має коригувати крок наступний і навіть саму технологію. Тому технологізація в умовах сучасної України є процесом інтерактивної діяльності й постійної комунікації і взаємодії з учасниками змін. Визначені в нашому дослідженні правила задають лише напрям дій, але вони мають бути обов'язково підкориговані ситуацією змін. Неупереджене бачення проблем, наявність образу кінцевої мети, здатність потрапляти «в резонанс» зі станом системи, на ходу вдосконалювати технологію -€ запорукою ефективності соціальної технології, яку використовує реформатор.

Перспектива подальших досліджень пов'язана з вивченням існуючих умов реалізації соціальної технології реформування сфери спорту, а також їхнього впливу на назрілу реформу сфери спорту.

\section{ЛITЕРАТУРА}

Бескровная, В. А. (2008). Государственное регулирование сфреры физкультурноспортивных услуг (методологические и организационно-экономические основы) (автореф. дис. ... докт. экон. наук: 08.00.05). Санкт-Петербург (Beskrovnaia, V. A. (2008). State regulation of the sphere of physical education and sports services (methodological and organizational-economic basis) (DSc thesis abstract). St. Petersburg).

Бурмыкина, И. В. (2013). Методологические основания теории социальных технологий современности. Вестник Московского университета. Сер. 18. Социология и политология, 4, 151-161 (Burmykina, I. V. (2013). Methodological foundations of the theory of modern social technologies. Bulletin of Moscow University. Ser. 18. Sociology and Political Science, 4, 151-161).

Гацуля, О. (2015). Розвиток галузевого управління у сфері фізичної культури та спорту: концептуальні засади. Державне управління та місцеве самоврядування, 1 (24), 176-185 (Hatzulia, 0. (2015). Development of sectoral management in the field of physical culture and sports: conceptual principles. Public Administration and Local Self-Government, 1 (24), 176-185). 
Герасимов, Б. Н., Чумак, В. Г. (2014). Социальные технологии в управлении. Самара (Gerasimov, B. N., Chumak, V. G. (2014). Social technologies in management. Samara).

Гонтарук, О. (2017). Проблеми та особливості розвитку сфери фізичної культури і спорту в контексті державно-приватного партнерства. Фізична культура, спорт ma здоров'я нації, 3 (22), 634-641 (Hontaruk, 0. (2017). Problems and peculiarities of physical culture and sports development in the context of public-private partnership. Physical Culture, Sports and Health of the Nation, 3 (22), 634-641).

Журба, М. А. (2017). Зарубіжний досвід державного регулювання сфери фізичної культури і спорту. Актуальні проблеми держави і права, 79, 51-57 (Zhurba, M. A. (2017). Foreign experience of state regulation of the sphere of physical culture and sports. Current Issues of State and Law, 79, 51-57).

Игнатенко, А. Спорт без реформы - Украина без медалей. Режим доступу: https:// www .unian.net/sport/othersports/1533531-sport-bez-reformyi-ukraina-bezmedaley.Html.pdf (Ignatenko, A. Sport without reform - Ukraine without medals. Retrieved from: https://www.unian.net/sport/othersports/1533531-sport-bezreformyi-ukraina-bez-medaley.Html.pdf).

Качуровский, Д. Спорт в Украине - перспективы, возможности, смыслы. Режим доступу: https://zn.ua/ internal/sport-v-ukraine-perspektivy-vozmozhnosti-smysly-246988_html (Kachurovskyi, D. Sport in Ukraine - prospects, opportunities, meanings. Retrieved from: https://zn.ua/internal/sport-v-ukraine-perspektivy-vozmozhnosti-smysly-246988 .html).

Куртинайтис, Р. Необходимо определиться $c$ приоритетами в спорте и финансировать их по максимуму. Режим доступу: http://www.dsnews.ua/politics/ rimas-kurtinaytis-neobhodimo-opredelitsya-sprioritetami-03032012_(Kurtinaitis, R. It is necessary to determine the priorities in the sport and finance them to the maximum. Retrieved from: http:// www.dsnews.ua/politics/rimas-kurtinaytis-neobhodimo-opredelitsya-sprioritetami-03032012100200).

Ларин, А. Ментальность властей - огромное препятствие для бизнеса в спорте. Режим доступу: http://hubs.ua/authority/a-larin-mental-nost-vlastej-ogromnoeprepyatstvie-dlya-biznesa-v-sporte-79523.html (Larin, A. The mentality of the authorities is a huge obstacle to business in sports. Retrieved from: http://hubs.ua/authority/a-larin-mental-nost-vlastej-ogromnoe-prepyatstvie-dlyabiznesa-v-sporte-79523.html).

Марков, М. (1982). Технология и эффрективность социального управления. Москва (Markov, M. (1982). Technology and the effectiveness of social management. Moscow).

Павленко, Ю. О. (2012). Організачійно-методологічні основи формування науковометодичного забезпечення підготовки начіональних команд до Олімпійських ігор (автореф. дис. ... док. наук з фіз. вих. та спорту: 24.00.01). Київ (Pavlenko, Yu. O. (2012). Organizational and methodological bases of formation of scientific and methodological support of preparation of national teams for the Olympic Games (DSC thesis abstract). Kyiv).

Попов, С. В. (2001). Искусство реформатора. Книга 1. Москва. (Рopov, S. V. (2001). The art of the reformer. Book 1. M oscow).

Попов, С. В. Что такое рефрормы? Режим доступу: http://ca-cpp.org/politic/5-chtotakoe-reformy.html (Popov, S. V. What are reforms? Retrieved from: http://cacpp.org/politic/5-chto-takoe-reformy.html). 
Приходько, В. В. (2018). Концепція управління сучасною системою підготовки спортсменів. Дніпро (Prykhodko, V. V. (2018). The concept of managing a modern system of training athletes. Dnipro).

Приходько, В. В. (2018). Направление, содержание и принципы реформы спорта высших достижений в Украине. Спортивний вісник Придніпров'я, 1, 308-313 (Prykhodko, V. V. (2018). The direction, content and principles of the reform of sports of the highest achievements in Ukraine. Prydniprovsky Sports Newsletter, 1, 308-313).

Приходько, В. В. (2014). Роль макропедагогики в создании концепции реформы спорта в условиях современной Украины. Спортивний вісник Придніпров'я, 1, 179-181 (Prykhodko, V. V. (2014). The role of macro pedagogy in creating the concept of sports reform in modern Ukraine. Prydniprovsky Sports Newsletter, 1, 179-181).

Приходько, В. В., Томенко, О. А., Михайличенко, О. В. (2016). Удосконалення організації та змісту наукових досліджень з фізичної культури і спорту в Україні як важлива передумова їх реформування. Педагогічні науки: теорія, історія, інноваційні технології, 3 (57), 419-429 (Prykhodko, V. V., Tomenko, O. A., M ykhailychenko, O. V. (2016). Improving organization and content of scientific studies on physical culture and sports in Ukraine as an important prerequisite for their reform. Pedagogical Sciences: Theory, History, Innovative Technologies, 3 (57), 419-429).

Советник министра молодежи и спорта: спонсирование спорта выведет деньги бизнеса из тени. Режим доступу: http://hubs.ua/authority/sovetnik-ministramolodezhi-i-sporta-sponsirovanie-sporta-vy-vedet-den-gi-biznesa-iz-teni88146.html. (Advisor to the M inister of Youth and Sports: sponsoring sports will bring business money out of the shadows. Retrieved from: http://hubs.ua/authority/ sovetnik-ministra-molodezhi-i-sporta-sponsirovanie-sportavy-vedet-den-gi-biznesa-iz-teni-88146.html).

Сурмин, Ю. П., Туленков, Н. В. (2004). Теория социальных технологий. Киев. (Surmin, Yu. P., Tulenkov, N. V. (2004). Theory of social technology. Kyiv).

Сутність стратегіï. Режим доступу: https://library.if.ua/book/101/6917.html. (The essence of strategy. Retrieved from: https://library.if.ua/book/101/6917.html).

Тактика. Режим доступу: https://uk.wikipedia.org/wiki. (Tactics. Retrieved from: https://uk. wikipedia.org/wiki).

Технология проведения рефрорм для страны с переходной экономикой и молодой демократией (2006). Москва (Reform technology for a country in transition and young democracy (2006). Moscow).

Шишигина, Т. Р., Лаздовский, Б. Б., Соловьева, А. В. (2012). Технологии социального управления. Санкт-Петербург (Shyshygina T. R., Lazdovsky, B. B., Soloviev, A. V. (2012). Social M anagement Technologies. St. Petersburg).

Шевчук, І. В. (2014). Організаційний механізм державного управління фізичною культурою і спортом на регіональному рівні. Інвестиції: практика та досвід, 14, 136-149 (Shevchuk, I. V. (2014). Organizational mechanism of state management of physical culture and sports at the regional level. Investments: Practice and Experience, 14, 136149).

Шинкарук, О., Дутчак, М., Павленко, Ю. (2013). Олімпійська підготовка спортсменів в Україні: проблеми і перспективи. Спортивний вісник Придніпров'я, 1, 82-86 (Shynkaruk, O., Dutchak, M., Pavlenko, Yu. (2013). Olympic Training of Athletes in Ukraine: Challenges and Prospects. Prydniprovsky Sports Newsletter, 1, 82-86).

Шинкарук, О. (2012). Особливості олімпійської підготовки спортсменів у зарубіжних країнах. Фізичне виховання, спорт і культура здоров'я у сучасному суспільстві, 1 (17), 126-129 (Shynkaruk, 0. (2012). Features of Olympic training of athletes in foreign 
countries. Physical Education, Sport and Health Culture in Modern Society, 1 (17), 126129).

Prykhodko, V., Tomenko, O. (2019). Innovative approach to the strategic management of the Olympic sport reform in Ukraine. Marketing and Management of Innovations, 1, 357366.

\section{PEЗЮME}

Приходько Владимир, Томенко Александр, Босько Василий, Бермудес Диана, Балашов Дмитрий. Проблема технологии в реформе сферы спорта в Украине.

Целью исследования является обоснование проблемы использования социальных технологий в ходе подготовки и проведения реформы сферы спорта. Методы исследования: анализ и обобщение литературных источников и материалов сети Internet, синтез, абстрагирование, индукция и дедукция. В статье представлены результаты критического анализа вполне качественных предложений ученых по реформированию сферы спорта, которые могут даже быть выбраны в качестве стратегии необходимых изменений. Смысл их критики заключается в демонстрации недостаточности одной только, даже качественно разработанной стратегии для начала нужных преобразований. Средством эфрфективного влияния на процесс изменений является специально созданная социальная технология реформирования сферы спорта, общие требования к подобным технологиям определены и описаны.

Ключевые слова: реформа сферы спорта, стратегия реформы, реформатор, положительная, отрицательная и ситуативная части изменений в ходе реформы, социальная технология.

\section{SUM MARY}

Prykhodko Volodumyr, Tomenko Oleksandr, Bosko Vasyl, Bermudes Diana, Balashov Dmytro. The problem of technology in the reform of the sports sector in Ukraine.

The article is devoted to substantiation of the issue of using technology in sports reform in Ukraine. The relevance of the study is determined by the fact that even presence of an officially adopted reform strategy does not provide the opportunity to move on to overdue changes to ensure a higher level of the sports sector. The purpose of the study is to substantiate the problem of using social technologies during the preparation and implementation of the reform of the sports sector and, as a result, in the formation of a modern system of training athletes. The methods of theoretical research were used: a synthesis of literature and materials from the Internet, abstracting, analysis and synthesis, induction and deduction, idealization and generalization.

The article presents the results of a critical analysis of quite high-quality proposals by scientists to reform the sports sector, which can even be selected as a strategy for the necessary changes. The point of their criticism is to demonstrate the insufficiency of only one, even a well-developed strategy for starting the necessary transformations. A means of effectively influencing the process of change is a specially created social technology for reforming the sports sector, the general requirements for such technologies are defined and described. In addition, a person who has self-determined as a reformer must have an attitude to be attentive to the existing situation with training of athletes. It is necessary that there is no desire to change it by force to the existing image of the future, because the real reformer is trying to be the one who sows the "seeds of the future", or the gardener who grafts the desired bud to the rootstock. For this, it is necessary not only to respect the existing reality, 
no matter how far it is from the ideals of reform, but also to be able to work realistically with one's ideas about the future.

Key words sports sector reform, reform strategy, reformer, positive, negative and situational parts of changes during the reform, social technology.

Удк [37.037:37.018.2] 796. 015.58

\author{
Євгеній Проскуров \\ Харківська гімназія № 14 \\ ORCID ID 0000-0002-4428-1743 \\ Олег Камаєв
}

Харківська державна академія фізичної культури

ORCID ID 0000-0003-4358-888X

DOI 10.24139/2312-5993/2019.07/116-130

\title{
ОСОБЛИВОСТІ МЕТОДИКИ ПІДВИЩЕННЯ МОТОРНОЇ ЩІЛЬНОСТІ УРОКІВ ФІЗИЧНОЇ КУЛЬТУРИ В ШКОЛІ З ВИКОРИСТАННЯМ СТАТИЧНИХ ВПРАВ
}

Стаття присвячена пошуку найбільш ефективних засобів підвищення зайнятості учнів 5-6-х класів на уроках фрізичної культури за модулем «Баскетбол». Проведені педагогічні спостереження, педагогічний експеримент, порівняльний аналіз, дозволили встановити, що доповнення навчального матеріалу спеціалізованим комплексом статичних вправ на силу, силову витривалість, гнучкість дозволило значно підвищити моторну щільність уроків із вказаного модулю. Даний комплекс вправ дозволяє охопити всіх школярів, однак це пов'язано з повною відсутністю командних дій, боротьбою та взаємозалежністю від інших учнів. Отримані результати свідчать, що статичні вправи можуть бути рекомендовані до шкільної програми в розділ спеціальної фізичної підготовки.

Ключові слова: статичні вправи, спеціалізовані комплекси,спеціальна фрізична підготовка, щільність уроку, зайнятість учнів.

Постановка проблеми. Традиційно склалося так, що зміст навчального матеріалу сучасних уроки фізичної культури для школярів, особливо спортивно-ігрової спрямованості, планують на великій кількості динамічних вправ, принципово швидкісно-силової спрямованості, чим забезпечують не тільки ідеальну щільність, а й високу рухову активність на занятті. Однак, на практиці помічено, що зайнятість учнів упродовж навчальних годин, незалежно від добре спланованої щільності, буває дуже низькою.

Аналіз актуальних досліджень. Аналіз літературних джерел довів, що серед новітніх педагогічних зрушень останнього часу у фізичному вихованні термін «зайнятість учнів» зовсім не використовується, інша річ - коли мова йде про щільність заняття, тоді умовно розуміється нібито навчальний матеріал, який було сплановано щільно, що одночасно гарантує і добру зайнятість школярів на уроці незалежно від типу і поставлених завдань. Існує достатня кількість наукових праць, присвячених цьому питанню. Наприклад, 